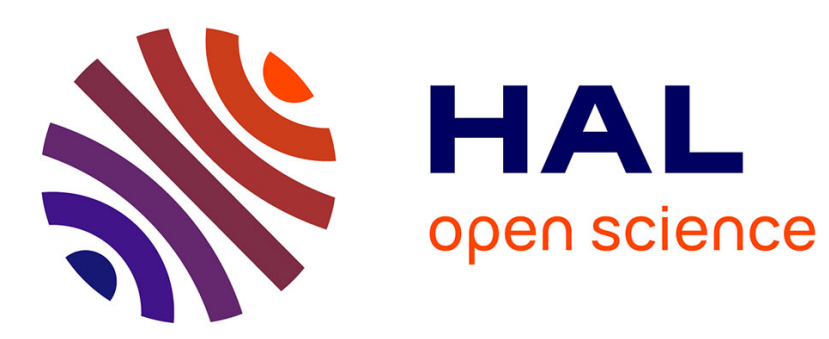

\title{
Building brand equity with environmental communication: an empirical investigation in France
}

Florence Benoît-Moreau, Béatrice Parguel

\section{To cite this version:}

Florence Benoît-Moreau, Béatrice Parguel. Building brand equity with environmental communication: an empirical investigation in France. EuroMed Journal of Business, 2011, 6 (1), pp.100-116. halshs00634443

\section{HAL Id: halshs-00634443 \\ https://shs.hal.science/halshs-00634443}

Submitted on 12 Jan 2012

HAL is a multi-disciplinary open access archive for the deposit and dissemination of scientific research documents, whether they are published or not. The documents may come from teaching and research institutions in France or abroad, or from public or private research centers.
L'archive ouverte pluridisciplinaire $\mathbf{H A L}$, est destinée au dépôt et à la diffusion de documents scientifiques de niveau recherche, publiés ou non, émanant des établissements d'enseignement et de recherche français ou étrangers, des laboratoires publics ou privés. 


\title{
Building Brand Equity with Environmental Communication:
}

\section{An empirical investigation in France}

Classification: Research paper

Benoît-Moreau F. ${ }^{1}$ and Parguel B. ${ }^{2}$

${ }^{1}$ Author of correspondence: Florence BENOIT-MOREAU

Paris-Dauphine University DRM-DMSP, Paris, France

31, rue de l'Eglise 86800 Saint Julien l'Ars France, +33 549578404

benoit_florence@hotmail.com

${ }^{2}$ Béatrice PARGUEL

Paris-Dauphine University DRM-DMSP and Paris Est University IRG, Paris, France

3, av. du Président Roosevelt 92330 Sceaux France, +33 147020625

beatrice.parguel@gmail.com

\begin{abstract}
About the authors:
Florence Benoit-Moreau is Marketing assistant Professor at Paris-Dauphine University, and member of DRM research center. She holds a Master degree in Business Administration from HEC Paris and worked as a consultant within the Boston Consulting Group (BCG) in Paris and London before starting her academic career.
\end{abstract}

Béatrice Parguel finished her $\mathrm{PhD}$ at Paris-Dauphine University and is working as a teaching assistant in Marketing at Paris Est University. 


\title{
Building Brand Equity with Environmental Communication:
}

\section{An empirical investigation in France}

\begin{abstract}
Purpose

Using Keller's (1993, 2003) brand equity framework, this paper investigates the impact of the firm's environmental communication on brand equity, and specifically its impact on brand image, through the strength and favourability of brand environmental associations.

\section{Design/methodology/approach}

A between-subjects experimental design tests the hypotheses with a generalisable sample of 165 French consumers.

\section{Findings}

Environmental communication positively influences the strength and favourability of brand environmental associations, therefore improving brand equity. Two moderators reinforce the impact of environmental communication on brand equity through the strength of brand environmental associations: the perceived congruence between the brand and the cause, and the perceived credibility of the claim.

\section{Practical implications}

In the context of greater consumer pressure regarding business ethics, managers should favour environmental arguments in their corporate communication to improve brand image through societal associations. Doing so, they should focus their communication on causes that are congruent with their brands to facilitate brand equity building, and ensure they are credible when proclaiming these arguments. 


\section{Originality/value of paper}

Despite existing research on corporate social responsibility (CSR), no studies focus on the specific impact of CSR communication on brand equity. This research provides initial empirical evidence about the positive effect of environmental claims on customer-based brand equity.

Keywords: CSR communication; environmental communication; brand equity; congruency; societal consciousness. 


\section{Introduction}

The interest for corporate social responsibility (CSR), born 50 years ago (Bowen, 1953), is strongly enhanced today as many companies and brands communicate about their societal initiatives in Europe. Among these societal claims, environmental ones dominate as ecology is the most typical domain of CSR (Mohr et al., 2001), and because some of them (like climate change) have achieved a tremendous media coverage (Peattie et al., 2009). In Europe, many brands use environmental claims in their ads. For example, in France in 2007, 3\% of mass media advertisements included messages about company actions to protect the environment, a threefold increase compared with 2006 (ARPP-Ademe, 2008). Such environmental communication practices develop, following consumers' growing societal awareness. In France, $68 \%$ of consumers think firms should pay more attention to the impact of their actions on the environment and social harmony (Sociovision 2005 Survey) and 54\% consider the environmental-friendly attribute as a very important criterion when choosing a product (IFOP 2008 in Le Monde, June 3, 2008).

From a strategical point of view, environmental communication practices take different forms from simply providing brief and general information, to turning firms' involvement into the heart of brand positioning (e.g., The Body Shop, Natura Brasil, Ben \& Jerry's or Stonyfield Farm, for which environmental involvement is the corner stone of their mission statement). In practice, firms usually advertise their environmental involvement through corporate or brand Web sites, relationship marketing tools (e.g., newsletters, consumer magazines, catalogues) or mass-media advertising (e.g., Carrefour and its outdoor advertising campaigns in France).

In a context where consumers challenge brands added value and become more critical, societal initiatives and therefore communication about them appear as a key strategic lever to build brand equity (Keller, 2003). Recent empirical works of research have studied the impact 
of the firm's societal initiatives (whether environmental or social) on consumers. They generally demonstrate a positive impact on the attitude towards the product or the firm and on consumers' purchase intent (Brown and Dacin, 1997; Creyer and Ross, 1997; Murray and Vogel, 1997; Folkes and Kamins, 1999; Ellen et al., 2000; Mohr et al., 2001; Sen and Bhattacharya, 2001; Swaen and Vanhamme, 2004, 2005; Mohr and Webb, 2005). Furthermore, while several academic studies have proposed that societal initiatives and related communication can actively build brand equity (Hoeffler and Keller, 2002; Keller, 2003; Bhattacharya et al., 2004), none have tested it yet. Filling this gap is important: building brand equity is still a major marketing issue as it increases marketing-mix efficiency, as well as the probability of success of brand extensions (Keller, 1993, 2003; Erdem and Swait, 1998).

Therefore, in this paper, we propose that societal communication, and more specifically environmental communication, contributes to brand equity building. We derive hypotheses from Keller's $(1993,2003)$ brand equity framework and experimentally test them in the case of a corporate brand. The study shows that environmental communication generally increases brand equity, and also assesses the influence of situational variables on brand equity building, such as the perceived congruency between the brand and the cause supported, and the perceived credibility of the environmental claim. The following section reviews the literature on the concepts of CSR and societal communication, and on their effects on consumers' response. Next, the paper presents the conceptual framework, the experimental methodology and its results, and finally discusses its implications and limitations, and potential routes for future research. 


\section{Literature review}

\section{CSR and CSR communication}

CSR covers a vast field of research (e.g., history, strategy, risk management, marketing, accounting/auditing/reporting, human resources), and definitions abound. In a broad perspective, CSR aims at "achieving commercial success in ways that honour ethical values and respect people, communities and the natural environment" (Bhattacharya and Sen, 2004, p.13). This conceptualisation includes a lot of practices and denominations: corporate societal marketing (Hoeffler and Keller, 2002), business ethics (Creyer and Ross, 1997) or causerelated marketing (Ellen et al., 2000). To circumscribe these various practices, this paper adopts a generic typology of CSR dimensions, making a distinction between environmental (how a business uses natural resources) and social responsibilities (how a business relates to the community in which it operates), and actually focuses on one of these dimensions: the environmental one. It follows the European Commission definition of CSR as "the voluntary integration of social and environmental concerns in the enterprises' daily business operations and in the interaction with their stakeholders" (DG Enterprise, Observatory of European SMEs, Report 2002 / No. 4: European SMEs and Social and Environmental Responsibility). Indeed, since the 90's, the study of CSR has been inscribed in the general stakeholder theory (Clarkson, 1995; Donaldson and Preston, 1995; Murray and Vogel, 1997), stating that firms allocate their resources and make decisions in order to satisfy stakeholders (e.g., shareholders, lobbies, employees, consumers). Though largely ignored as stakeholders so far, consumers are now under focus, as they become a more critical and powerful pressure group under the influence of consumer movements and non-governmental organisations (NGOs). This interest for consumers as a strategic target can explain the development of CSR communication, which appears to be a key lever to provide more information regarding CSR practices. 
As an aspect of corporate communication, CSR communication "is designed and distributed by the company itself about its CSR efforts" (Morsing, 2006, p.171) and can reflect three potential approaches (Van de Ven, 2008). The reputation management approach focuses "on the basic requirements of conducting a responsible business to obtain and maintain a license to operate from society" (Van de Ven, 2008, p.345) and implies no explicit CSR communication. The second approach, building a virtuous corporate brand, means making an "explicit promise to the stakeholders and the general public that the corporation excels with respect to their CSR endeavours" (Van de Ven, 2008, p.345), which clearly suggests CSR communication. In this sense, two communication instruments are available (Van de Ven, 2008): corporate communication instruments (e.g., CSR reporting, publication of ethical codes, Web sites) and marketing communication instruments (e.g., advertising, sponsoring, direct marketing and promotions, public relations). The latter, which can be overly salient, are riskier and therefore remain less common, despite some recent rapid growth. The third, ethical product differentiation approach means "differentiating a certain product or service on the basis of an environmental or social quality" (Van de Ven, 2008, p.348). In this case, CSR efforts constitute the heart of brand positioning (e.g., The Body Shop, Natura Brasil), which makes CSR communications natural and inevitable.

Although managers have long followed the principle: Do good and let other talk about it (Kotler and Lee, 2005), the use of CSR communication is growing, because it provides a corporate marketing tool that can build a strong corporate image and reputation (Hoeffler and Keller, 2002) and achieve social legitimacy (Morsing, 2006). However, we know little about how consumers actually respond to it.

The effects of CSR and CSR communication on consumers 
Most empirical studies put in evidence the strong negative impact of the company's alleged irresponsible acts (e.g., air and water pollution, child labour, human rights violations) on attitude towards the firm (Murray and Vogel, 1997; Folkes and Kamins, 1999; Mohr et al., 2001), as well as on attitude towards the product and purchase intent (Murray and Vogel, 1997; Swaen and Vanhamme, 2004, 2005). More recently, Mohr and Webb (2005) have demonstrated an asymmetrical impact of societal practices on consumers' perceptions, which had already been suggested by Creyer and Ross (1997): good performances in terms of CSR positively influence consumers' attitude towards the firm and purchase intent, but bad performances damage them even more. However, this negative relation may depend on consumers' attributions of blame (Klein and Dawar, 2004). While the negative impact of irresponsible acts is unambiguous, the positive effect of good societal performances is more controversial (Brown and Dacin, 1997; Sen and Bhattacharya, 2001; Swaen and Vanhamme, 2004; Mohr and Webb, 2005). This effect is to be shown in the attitude towards the firm, but not systematically in the attitude towards the product or purchase intent (Brown and Dacin, 1997; Swaen and Vanhamme, 2004). To add to this body of research on consumers' perceptions of societal practices, academics also study the moderating effects of different variables. Some explore situational moderators such as the firm's perceived involvement (Ellen et al., 2000; Becker-Olsen et al., 2006) or perceived company-cause congruency (Ellen et al., 2000; Sen and Bhattacharya, 2001; Becker-Olsen et al., 2006). Others investigate individual moderators such as consumers' tendency to behave socially (Klein and Dawar, 2004; Mohr and Webb, 2005) or consumers' degree of support for the cause (Sen and Bhattacharya, 2001; Mohr and Webb, 2005).

If CSR initiatives have already a long history, communicating proactively about them is more recent and dates back to the 90's. That is why the specific effects of proactive CSR communication have received little attention in marketing research so far. Schlegelmilch and 
Pollach (2005) generally discuss the perils and opportunities of communicating corporate ethics. Other works focus on the effect of previous CSR communication in the case of a crisis (Swaen and Vanhamme, 2004; Vanhamme and Grobben, 2009).

Concerning the specific effects of environmental communication, independently from the CSR body of research aforementioned, several research works have been published in the early 90's, in a specific American context, under the term 'green advertising'. Green advertising is defined as "any ad [...] that 1-explicitely or implicitly addresses the relationship between a product or the biophysical environment, 2-promotes a green lifestyle [...] or 3-presents a corporate image of environmental responsibility" (Banerjee et al., 1995, p.22). Apart from proposing typologies of environmental claims (Carlson et al., 1993; Banerjee et al., 1995), they also examine several conditions of claims' efficacy on consumers. They note that specific and detailed claims are more persuasive than vague and ambiguous ones (Kangun et al., 1991; Davis, 1994). Davis (1994) shows that claim emphasis also plays a role: when the environmental attribute is presented as a second attribute behind a more central one, consumers perceive the ad as less manipulative than when the environmental claim is the main one. Obermiller (1995) demonstrates the importance of the message formulation: a "sick baby" appeal (i.e., a message emphasizing the severity of the problem) is more efficient than a "well baby" appeal (i.e., a message stressing the significance of individual action), when concern for the environmental problem is high (but less efficient in the opposite case). Surprisingly, Schuhwerk and Lefkoff-Hagius (1995) show that for people highly involved with the environment, there is no significant difference of efficacy between a green appeal or a cost-saving appeal, whereas a green appeal is superior for people weakly involved, probably because the first ones are more sceptics towards green claims. Later, in a Chinese context, Chan (2000) demonstrates that the country of origin of the product being advertised also plays a role: the more eco-friendly the country, the more persuasive the ad. More recently, in the 
UK context, Peattie et al. (2009) review the challenges private and public sectors face to communicate about climate change and encourage ecological behaviours.

At this stage, numerous questions remain unanswered, specifically in a European context: is CSR communication advisable? which practices should be advertised? towards which target? is credibility important, and if so, does it come from the message itself or from its source (Swaen and Vanhamme, 2005)? which media are the best to communicate about societal involvement? Knowledge about CSR communication is clearly still limited. As a first step, the general mechanism of brand equity building through CSR communication (specifically through environmental communication in this paper), discussed at a pure theoretical level (Hoeffler and Keller, 2002), should be empirically studied.

\section{Theoretical framework}

Focusing on consumers' perceptions, the present research adopts Keller's (1993, 2003) general customer-based approach, which is the most commonly used in marketing research (Czellar and Denis, 2002). Keller (2003, p.60) defines brand equity as "the differential effect that brand knowledge has on consumer response to the marketing of that brand" and measures it through the cognitive antecedents of consumers' brand knowledge. As in Keller's framework, we consider brand knowledge as a composition of brand attention and brand image. Any change in the marketing-mix that affects brand attention or image communication actions or possible alliances with other brands, events, causes - influence brand knowledge, and therefore brand equity. In this research, we control brand attention and concentrate on the influence of environmental communication on brand equity through its effects on brand image.

According to the associative network theory (Bower, 1981; Mitchell, 1982), brand image is composed of all the associations linked to the brand in consumers' minds. These 
associations mirror the meaning of the brand for consumers. Three dimensions characterise them: their strength, favourability and uniqueness (Keller, 1993, 2003). Strength qualifies the intensity of the connection between the associations and the brand. Strong associations help speed up the reactivation of information stored in memory. Favourability measures the desirability of the associations. Uniqueness assesses the degree of specificity of the associations to the brand (whether associations are shared with competitors or not). Finally, customer-based brand-equity depends on the strength, the favourability and the uniqueness of brand associations (Keller, 1993, 2003; Krishnan, 1996). In this research, we specifically investigate the impact of environmental communication on the two main dimensions of brand associations - strength and favourability of associations - and on a more global measure of brand equity.

\section{Effects of environmental communication}

At a theoretical level, Hoeffler and Keller (2002) specifically discuss the impact of CSR on customer-based brand equity. They argue that CSR can enhance brand image by generating new abstract associations, associations to the cause itself, associations related to an idealised brand user, or associations related to brand personality (the brand may appear as more sincere, caring or genuine). When the brand communicates about its CSR initiatives, in particular its environmental initiatives, it draws consumers' attention on environmental associations specifically, therefore reinforcing their strength.

Furthermore, as firms fully control the way they communicate about their environmental involvement, they do so in order to convey a positive image of them in line with consumers' expectations. According to a survey conducted in 2008 by IFOP (Le Monde, June 3, 2008), consumers pay more and more attention to firms' societal responsibility when buying and consuming, and evaluate positively those firms that behave with diligence. More theoretically, 
environmental communication generates other-oriented intrinsic value (Holbrook, 1996). It provides different hedonic benefits such as a self-expression benefit (Chandon et al., 2000), as consumers can display their values around them (Hoeffler and Keller, 2002), or an experiential benefit, as consumers have the impression to contribute to general well-being. Therefore, when a brand communicates about its environmental involvement, it reactivates these hedonic and experiential benefits, and reinforces the favourability of brand environmental associations.

Given these two discussions, Hypothesis 1 is:

H1: Environmental communication enhances the strength (Hla) and the favourability (H1b) of brand environmental associations, as well as brand equity (H1c).

As noted formerly, associating the brand with another entity or a cause can improve brand knowledge, depending on the transferability of this knowledge from the endorser to the brand (Keller, 1993, 2003). Claim perceived characteristics may facilitate knowledge transferability and therefore emphasise the effect of environmental communication on brand equity, such as the perceived congruency between the brand and the cause supported, and the perceived credibility of the environmental claim.

Effects of the perceived congruency between the brand and the cause supported

Cause-related communication efficiency depends on key variables such as the congruency of donations (i.e., product rather than cash contributions) with the firm's core business (Ellen $e t$ al., 2000) or overall brand-cause congruency (Hoeffler and Keller, 2002; Motion et al., 2003; Hamlin and Wilson, 2004; Becker-Olsen et al., 2006). Congruency is conceptualised as the degree to which two elements of a pair are perceived as being well assorted (Park et al., 1991). In case of high congruency between the brand and the cause supported, consumers infer more 
associations (Hoeffler and Keller, 2002) that are clearer and less ambiguous (Erdem and Swait, 1998) and more likely to match existing cognitive structure (Becker-Olsen et al., 2006). Hence, higher congruency generates stronger environmental associations. Alternatively, lower congruency generates inferences that are harder to organise within consumer existing brand knowledge, and therefore weaker environmental associations.

Thus, the discussion leads to Hypothesis 2:

H2: In case of environmental communication, the perceived congruency between the brand and the cause supported increases the strength of brand environmental associations (H2a), and therefore brand equity (H2b).

\section{Effects of the perceived credibility of the environmental claim}

Moreover, environmental communication efficiency depends on the perceived credibility of the environmental claim (Erdem and Swait, 1998). As an illustration, CSR information coming from a commercial source should be perceived as less credible than the same information coming from an independent organisation (Mohr et al., 2001), or from consumers' organisations (Swaen and Vanhamme, 2005). The perceived credibility of the environmental claim could consequently influence consumers' decision to interpret, encode and stock the message related to societal involvement. On the other hand, non-credible information may prevent the construction of strong associations. The perceived credibility of the environmental claim then appears as a necessary condition to build strong environmental associations.

Therefore, we postulate that:

H3: In case of environmental communication, the perceived credibility of the environmental claim increases the strength of brand environmental associations (H3a), and therefore brand equity (H3b). 
Figure 1 represents the entire conceptual framework.

Insert Figure 1 about here

\section{Methodology}

\section{Experiment and stimuli}

Testing the conceptual framework implies to compare the relative effect on brand equity of two similar communications, one showing environmental claim, the other not (control group).

Brand and sector. In both conditions, we first present D'ECO, a fictitious retailer in the furniture and home improvement industry, by showing the respondents a corporate Web site home page (see Appendix 1). We choose a fictitious corporate brand, as in many previous studies (Brown and Dacin, 1997; Swaen and Vanhamme, 2005), to avoid any effects of prior brand familiarity (we checked the availability of the brand name and verified respondents were unfamiliar with it: mean $=1.56$ on a seven-point scale). The case of a retailer is of particular interest as CSR communication is a very common practise in retail (Jones et al., 2007). Furthermore, for the choice of the product category, we rejected several industries because of their high environmental involvement (e.g., energy), for which ceiling effects might occur, and others that are intrinsically controversial (e.g., automotive, oil and gas), which might boost consumers' suspicion. In contrast, the furniture and home improvement industry is an experience-driven category, which makes brand equity more critical (Erdem and Swait, 1998). Furthermore, in this sector, many brands (e.g., IKEA) employ a simple brand architecture, in which their corporate brand is the same as their commercial and outlet brands. This characteristic helps remove ambiguity about brand equity inferred by consumers. To increase task involvement, the experiment indicates that the fictitious company is a real retailer considering a launch in France. 
Environmental communication medium. Previous academic research have used many different media as stimuli for CSR communication: company profile (Brown and Dacin, 1997), radio scripts (Ellen et al., 2000), press release (Swaen and Vanhamme, 2004), consumers' associations articles (Swaen and Vanhamme, 2005) or newspapers articles (Becker-Olsen et al., 2006). The present research considers the brand Web site (specifically the brand presentation Web page) for four main reasons. First, a Web site is the most frequent medium used to engage in CSR corporate communication (Van de Ven, 2008); in the United States, $80 \%$ of Fortune 500 companies mention their involvement on their Web sites (Bhattacharya and Sen, 2004). Such societal communication generally requires a highly accessible but inexpensive medium to avoid accusations of spending more on communication than on the initiatives themselves (Varadarajan and Menon, 1998; Schlegelmilch and Pollach, 2005). Second, Web sites are a preferred medium to communicate CSR involvement because of the richness of argumentation and opportunities for interactivity they provide (Coupland, 2005). Jones and colleagues (2007) underline its "interactivity, updatability and ability to handle complexity". Third, for product categories such as furniture and home improvement, Web sites are widespread; $47 \%$ of French consumers look for information on the Internet before buying furniture in an outlet (Netratings French Panel, 2006). Fourth, brand Web sites can target the best brand clients and influence their attitudes and perceptions of the brand's personality (Müller and Chandon, 2004). We therefore anticipate that online CSR communication influences brand equity after a single exposure, because corporate image generally is malleable compared with corporate reputation and can be modified rapidly through adequate communication (Gray and Balmer, 1998).

The brand presentation Web page stimulus features four elements: timeline, facts \& figures, our vision, and our engagements. In the control group, general press information replaces the fourth block, "our engagements" (see Appendix 2). To ensure realism, we use 
IKEA's engagements (i.e., producing furniture with wood from certified forests) as inspiration for the environmental claims. Furthermore, engagements regarding raw materials are very common in retailers' CSR communication strategy (Jones et al., 2007).

\section{Procedure}

The data collection relied on a Web survey, and the experiment consisted of two stages. First, the home page introduced the D'ECO Company and the product categories it sells. Second, respondents read the Web page stimulus (see Appendix 2). Then, they completed the rest of the questionnaire with no possibility of going back to review the Web pages. In the 'environmental communication' condition, only respondents who noticed that D'ECO supported a cause remain in the final data sample.

To access a generalisable sample, we recruited 165 respondents from the online panel of a professional market research institute. Respondents are between 25 and 45 years of age (mean $=33$ ). The sample represents various areas in France and is heterogeneous in terms of gender and socio-economic status. We randomly assigned the subjects to each of the two treatments.

\section{Measures}

All constructs use seven-point scales: brand equity, the congruency between the brand and the cause supported, the perceived credibility of the environmental claim, the strength and the favourability of associations, as well as consumers' societal consciousness, an individual characteristic, which is introduced as a covariate.

Defined as "the tendency for the consumer to purchase products and services which he/she perceives to have a positive (or less negative) impact on the environment, or to use his/her purchasing power to express current social concerns" (Roberts, 1995), consumers' 
societal consciousness moderates the influence of societal marketing on the firm's evaluation (Sen and Bhattacharya, 2001), or on the intention to endeavour a responsible behaviour (Mohr et al., 2001; Mohr and Webb, 2005) in previous research. As conscious consumers specifically support societal initiatives, environmental communication has a stronger personal resonance among them, which justifies considering it as a covariate in our analyses.

To assess consumers' social consciousness and the perceived credibility of the claim, we develop ad hoc scales. For the other measures, we rely on previously validated scales. We conduct checks for unidimensionality and reliability for the multi-items scales and find satisfactory reliability (see Table 1). We use mean item scores to measure the constructs.

Insert Table 1

Table 1: Scales

\begin{tabular}{|c|c|c|}
\hline Variable & Instrument & $\begin{array}{c}\text { Reliability } \\
\text { (Cronbach's } \alpha)\end{array}$ \\
\hline Brand equity & Three items from Yoo and Donthu (2001) & 0.91 \\
\hline $\begin{array}{l}\text { Consumers' societal } \\
\text { consciousness }\end{array}$ & $\begin{array}{l}\text { Three ad hoc items } \\
\text { - I try not to buy from companies that strongly pollute. } \\
\text { - When possible, I systematically choose the product that } \\
\text { has the lowest negative impact on the environment. } \\
\text { - When I have the choice between two equivalent products, I } \\
\text { always wonder which one pollutes less before buying. }\end{array}$ & 0.90 \\
\hline $\begin{array}{l}\text { Congruency between the } \\
\text { brand and the cause supported }\end{array}$ & Three items from Fleck and Quester (2007) & 0.95 \\
\hline $\begin{array}{l}\text { The perceived credibility of } \\
\text { the environmental claim }\end{array}$ & $\begin{array}{l}\text { Three ad hoc items } \\
\text {-The Web page information are true } \\
\text { - I believe in the information provided by this Web site } \\
\text { - This Web site is fair in what is said and shown }\end{array}$ & 0.92 \\
\hline Strength of associations & $\begin{array}{l}\text { Please indicate the degree of association of each of the } \\
\text { following attributes to the brand D'ECO? (Keller, 1993, 2003) } \\
\qquad-3=\text { very weak / +3=very strong }\end{array}$ & \\
\hline Favourability of associations & $\begin{array}{c}\text { In your opinion, is it positive or negative for the brand D'ECO } \\
\text { to have this image? (Keller, } 1993,2003 \text { ) } \\
-3=\text { very negative } /+3=\text { very positive }\end{array}$ & \\
\hline
\end{tabular}


The associations to be assessed come from a qualitative pre-test where 31 consumers were asked to consider the stimuli and to elicit free associations (Van Riel et al., 1998). In reaction to the environmental engagement, the brand association mostly cited was ecological. As filler tasks, three other associations were measured for young people, low prices, design.

As a manipulation check, at the end of the questionnaire, we asked the respondents (on a seven-point scale) if the D'ECO Web site was providing information regarding the retailer's environmental involvements. There was a significant difference across the two treatments (means of 6.3 for the 'environmental communication' condition vs. 5.1 for the control group, $\mathrm{p}<.000$ ), showing the manipulation's success.

\section{Results}

Table 2 shows scales' means and standard deviations for each of the experimental treatments. Insert Table 2

\section{Table 2: Descriptive statistics per treatment (on seven-point scales)}

\begin{tabular}{|c|c|c|c|c|c|c|c|}
\hline & & $\begin{array}{c}\text { Societal } \\
\text { consciousness }\end{array}$ & $\begin{array}{l}\text { Perceived } \\
\text { congruency }\end{array}$ & $\begin{array}{l}\text { Perceived } \\
\text { credibility }\end{array}$ & $\begin{array}{l}\text { Environmental } \\
\text { association } \\
\text { strength }\end{array}$ & $\begin{array}{l}\text { Environmental } \\
\text { association } \\
\text { favourability }\end{array}$ & $\begin{array}{l}\text { Brand } \\
\text { equity }\end{array}$ \\
\hline \multirow{2}{*}{$\begin{array}{c}\text { Environmental } \\
\text { communication } \\
(\mathrm{N}=115)\end{array}$} & Mean & 4.3 & 5.7 & 5.0 & 6.1 & 6.4 & 4.9 \\
\hline & $\begin{array}{r}S t d \\
d e v\end{array}$ & 1.4 & 1.0 & 1.2 & 1.3 & 1.0 & 1.3 \\
\hline \multirow{2}{*}{$\begin{array}{l}\text { Control Group } \\
\qquad(\mathrm{N}=50)\end{array}$} & Mean & 4.2 & - & - & 5.3 & 5.4 & 4.4 \\
\hline & $\begin{array}{c}\text { Std } \\
\text { dev. }\end{array}$ & 1.4 & - & - & 1.2 & 1.4 & 1.1 \\
\hline
\end{tabular}

Before testing the hypotheses, to replicate previous findings (Keller, 1993, 2003; Krishnan, 1996) in the specific case of environmental associations the authors have checked the influence of the strength and the favourability of the association ecological on customerbased brand equity. A Pearson correlation test reveals a significant and positive correlation between the strength of the association ecological and brand equity (Pearson $=0.5, \mathrm{p}<.000$ ), 
and between the favourability of the association ecological and brand equity (Pearson $=0.4$, $\mathrm{p}<.05)$. Thus, customer brand-equity increases with the strength and the favourability of the association ecological.

Then, H1 is tested with a t-test of the equality of means. Supporting H1a and H1b, the strength (means of 6.1 vs. 5.3, p <.000) and the favourability (means of $6.4 v s .5 .4, \mathrm{p}<.000$ ) of the association ecological are significantly higher when the brand communicates about its environmental initiative than when it does not. Supporting H1c, brand equity is also significantly higher $($ mean $=4.9$ ) when the brand communicates than when it does not (mean $=4.4$ in the control group, $\mathrm{p}<.05$ ). Thus environmental communication has a significant effect on brand image environmental dimensions, and therefore on brand equity.

A linear regression model is used to test the other hypotheses with the strength of the association ecological and brand equity as successive dependent variables. The perceived congruency between the brand and the cause supported and the perceived credibility of the claim are introduced as independent variables. Societal consciousness is introduced as a covariate. Table 3 summarises the results.

Insert Table 3

Table 3: Results of the linear regressions

\begin{tabular}{|c|c|c|c|}
\hline Dependent Variable $(\mathbf{Y})$ & Independent Variables $\left(\mathbf{X}_{\mathrm{i}}\right)$ & Adj $\mathbf{R}^{2}$ & Sd $\beta$ \\
\hline Strength of the association ecological & (intercept) & $0.321 * * *$ & $0.378^{* * *}$ \\
& Perceived congruency & $0.276^{* *}$ \\
& Perceived credibility & -0.023 \\
\hline Brand equity & Societal consciousness & $0.359 * * *$ & \\
& Perceived congruency & & $0.335^{* * *}$ \\
& Perceived credibility & & $0.355^{* * *}$ \\
\hline
\end{tabular}

$* * * p<.001, * * p<.01, * p<.05$ 
Both regressions are significant. The results show that the congruency between the brand and the cause supported significantly increases the strength of the association ecological $(\beta=0.4 * * *)$ and brand equity $(\beta=0.3 * * *)$ : $\mathrm{H} 2 \mathrm{a}$ and $\mathrm{H} 2 \mathrm{~b}$ are then supported. The perceived credibility of the claim also significantly increases the strength of the association ecological $\left(\beta=0.3^{* *}\right)$ and brand equity $\left(\beta=0.4^{* * *}\right)$ : $\mathrm{H} 3 \mathrm{a}$ and $\mathrm{H} 3 \mathrm{~b}$ are then also supported. Surprisingly, consumers' societal consciousness has no significant effect either on the strength of the association ecological or on brand equity.

\section{Discussion}

The present research investigates the role of environmental communication in the mechanisms of brand equity building. The experiment exposes subjects to one of two different versions of a brand presentation Web page, showing or not an environmental claim. As postulated, and consistent with the brand equity building principles described by Keller (1993), the results validate that environmental communication has a positive impact on the strength and favourability of brand environmental associations, and therefore on brand equity. Furthermore, they show that several situational factors reinforce the effect of environmental communication on brand equity building. This effect increases with the congruency between the brand and the cause supported and with the perceived credibility of the claim, thanks, in both cases, to an increase in the environmental association strength. Tested as a covariate, consumers' societal consciousness seems not to have any influence on brand equity, but this may due to the strong social desirability elicited by the concept, or the fact that there is a strong gap between consumers' declared attitude and effective behaviour, especially in the environmental domain (Peattie et al., 2009). Further replications should be performed before concluding on that point. On the basis of this work, meaningful implications can be identified. 


\section{Implications}

From a theoretical point of view, this research provides an initial piece of evidence of the empirical positive impact of environmental claims on customer-based brand equity. Surprisingly, this important result has never been empirically demonstrated, specifically on a generalisable sample in Europe, where environmental communication is quickly developing, but research is still scarce. Consistent with the general assumption that an alliance with another entity generates associations' transfers that contribute to modify or reinforce brand equity (Keller, 1993, 2003), the experiment validates that getting involved in an environmental cause and communicating about this engagement to consumers also reinforce brand equity, by modifying brand image (Hoeffler and Keller, 2002). This kind of communication generates or at least reinforces the specific ecological association. As an abstract association, the ecological association should exhibit a better transferability in case of brand extensions (Park et al., 1991). Therefore, the integration of the ecological association is a way to enrich brand imagery.

Second, the present research also replicates previous work on the positive effect of the congruency between the brand and the chosen endorser on brand equity building (Hoeffler and Keller, 2002; Motion et al., 2003; Becker-Olsen and Hill, 2006). Again, we validate that the stronger the congruency the better the transferability of associations. A strong congruency between the brand and the cause supported is probably a boundary condition to create brand differentiation.

Third, the present research confirms previous seminal work (Mohr et al., 2001; Swaen and Vanhamme, 2005) on the role of the credibility of societal communication in brand equity building. In the actual context of "greenwashing" mentioned earlier, the perceived credibility of the claim may appear as a pivot variable to explain environmental advertising efficiency. Furthermore, this research demonstrates that, as supposed, brand Web site can be an accurate 
and credible medium (obtaining a mean score of credibility of 4.8 out of 7), probably more than traditional advertising (Banerjee et al., 1995).

From a managerial point of view, the present research has also immediate implications. Managers now have in hands theoretical arguments to justify their environmental communication practices, not just relying on the fact that many brands use these arguments. In a general manner, if properly done, environmental communication can contribute to build brand equity by generating or reinforcing environmental image. However, managers have to pay attention to different factors influencing brand equity building. First, to maximise brand equity creation, they will have to ensure that their engagement is congruent with their brand, increasing in turn the transferability of environmental associations to the brand. They will also have to take care of their message credibility. This challenge will become more crucial in the future as observers notice the development of scepticism especially across young people. Firms should then choose highly credible media to communicate, instead of advertising or mere sponsorship. Communicating on the brand Web site gives the message an institutional dimension, which ensures a certain degree of credibility but a lot more could be investigated in terms of choice of media or about the impact of other communication formats, such as societal reporting, audited publication, codes of conduct or social labelling.

\section{Limitations and future research directions}

To conclude, this study presents several limitations and opens routes for future research. If this research proves a general positive effect of environmental communication on brand equity in certain favourable conditions, a lot more need to be investigated to understand the boundary conditions. Initial corporate reputation regarding societal issues, but also the anteriority of the brand's engagement in such societal initiative can moderate the positive impact of environmental communication and should be investigated. 
The present research also sheds light on the role of credibility, but does not envisage all sources of credibility. Further research could be done at the message level, at the source level (which brands are legitimate to communicate? is the anteriority of the societal practice important?) but also at the medium level (are there media that are best suited to deliver societal message?). Regarding this last specific point, the research focuses on only one type of communication medium to eliminate this specific source of variance, but future studies will have to generalise results to several media or on the contrary explain different kinds of effects. New emergent media such as those cited earlier (e.g., societal reporting, audited publication, codes of conduct or social labelling) should be investigated to understand their specific value. Again these questions should be examined considering the risk of perceptions of "greenwashing". Is there a minimum level of credibility under which brand equity could be damaged? Which factors (initial brand reputation? brand sector? legitimacy to communicate? medium used? executional factors?) may induce perceptions of manipulation and therefore make environmental communication damaging for the brand.

Furthermore, it would be interesting to extend knowledge on environmental communication intermediate effects leading to brand equity reinforcement. Several studies suggest that part of the answer may stem from a greater understanding of how consumers decode the motivations behind CSR communication (Dean, 2004; Pirsch et al., 2007; Van de Ven, 2008). Eventually, considering the attributions of firms' environmental involvement (Klein and Dawar, 2004; Sjovall and Talk, 2004) as a mediator between environmental communication and brand equity could also help deepen CSR efficiency understanding. This question is even more crucial in the actual context, because the profusion of CSR claims has prompted a movement that denounces those advertising agencies that encourage "greenwashing" (Bradford, 2007). If the present research shows that, in a "basic" case, when there is not any clue inducing any intent of "greenwashing", consumers do not necessarily question the claims, and therefore 
develop a positive attitude towards the brand, we can suppose that perceptions of “greenwashing" or deliberately misleading strategies can damage consumers' attitude toward a brand, and therefore brand equity.

Future research should also replicate the results to other cultural contexts, as societal consciousness seems to vary across them (Maignan and Swaen, 2000). Insisting on this point, Matten and Moon (2004) show that the way European and American envisage CSR initiatives are really different responding to the influence of their national business systems. In the same vein, examining the differences between transitional economies and mature ones could be interesting (Grbac and Loncaric, 2009).

Last but not least, the research should be replicated across different industries, or in a longitudinal perspective as industry maturity regarding CSR involvement, and especially environmental ones probably plays a role, certain engagements becoming prerequisite and no more value adding for the brand. Ceiling effects could therefore appear. Moreover, if all brands in the industry get involved in the same practices, the differentiation power of environmental claims decreases a lot. This assumption raises the question of a possible pioneer effect regarding the cause in which the brand engages.

\section{Conclusion}

This research is a first investigation of the effects of CSR communication, and specifically environmental communication on brand equity. Inscribed in Keller's consumer-based framework, it experimentally demonstrates, in the basic setting of a retailer's communication on its Website, the general positive impact of environmental communication on brand equity (through its influence on the strength and uniqueness of brand environmental associations). Furthermore, it shows the importance of two moderators: the perceived congruency between the brand and the cause supported, and the perceived credibility of the environmental claim. 
This is a first step only in this research direction, as many other boundary conditions should be investigated regarding the characteristics of the brand (legitimacy, own CSR history...) or of the communication (type of message, medium used...). 


\section{References}

Banerjee B., Gulas, C.S. and Iyer, E. (1995), "Shades of Green: A Multidimensional Analysis of Environmental Advertising", Journal of Advertising, Vol. 24 No 2, pp. 22-31.

Becker-Olsen, K.L., Cudmore, B.A. and Hill, R.P. (2006), "The Impact of Perceived Corporate Social Responsibility on Consumer Behavior", Journal of Business Research, Vol. 59 No 1, pp. 46-53.

Becker-Olsen, K.L. and Hill, R.P. (2006) "The Impact of Sponsor Fit on Brand Equity", Journal of Service Research, Vol. 9 No 1, pp. 73-83.

Bhattacharya, C.B. and Sen, S. (2004), "Doing Better at Doing Good: When, Why, and How Consumers Respond to Corporate Social Initiatives", California Management Review, Vol. 47 No 1, pp. 9-24.

Bhattacharya, C.B., Smith, N.C. and Vogel, D. (2004), "Integrating Social Responsibility and Marketing Strategy: An Introduction”, California Management Review, Vol. 47 No 1, pp. 6-8.

Bowen, H.R. (1953), Social Responsibilities of the Businessman, New York: Harper \& Row.

Bower, G.H. (1981), “Mood and Memory”, American Psychologist, Vol. 36, pp. 129-148.

Bradford, R. (2007), "Green Wash Confronted: Misleading Advertisement Regulation in the EU and its Member States", study report available at www.foeeurope.org/corporates/pdf/greenwash_confronted.pdf.

Brown, T.J. and Dacin, P.A. (1997), "The Company and the Product: Corporate Associations and Consumer Product Responses", Journal of Marketing, Vol. 61 No 1, pp. 68-84.

Carlson, L., Groves, S.J. and Kangun, N. (1993), "A Content Analysis of Environmental Advertising Claims: A Matrix Method Approach", Journal of Advertising, Vol. 22 No 2, pp. 27-39.

Chan, R.Y (2000), "The Effectiveness of Environmental Advertising: the Role of Claim Type and the Source Country Green Image", International Journal of Advertising, Vol. 19 No 3, pp. 349-375.

Chandon, P., Wansink, B. and Laurent, G. (2000) "A Congruency Framework of Sales Promotion Effectiveness", Journal of Marketing, Vol. 64 No 4, pp. 65-81.

Clarkson, M.E. (1995), “A Stakeholder Framework for Analyzing and Evaluating Corporate Social Performance", Academy of Management Review, Vol. 20 No 1, pp. 92-117.

Coupland, C. (2005), "Corporate Social Responsibility as Argument on the Web", Journal of Business Ethics, Vol. 62 No 4, pp. 355-366.

Creyer, E.H. and Ross, W.T. (1997), "The Influence of Firm Behavior on Purchase Intention: Do Consumers Really Care about Business Ethics?", Journal of Consumer Marketing, Vol. 14 No 6, pp. 421-432.

Czellar, S. and Denis, J-E. (2002), "Un Modèle Intégrateur du Capital-Client de la Marque : une Perspective Psycho-Cognitive, Recherche et Applications en Marketing, Vol. 17 No 1, pp. 43-55.

Davis, J.J. (1994), “Good Ethics is Good for Business: Ethical Attributions and Response to Environmental Advertising", Journal of Business Ethics, Vol. 13 No 11, pp. 873-885.

Dean, D. (2003), "Consumer Perception of Corporate Donations. Effects of Company Reputation for Social Responsibility and Type of Donation", Journal of Advertising, Vol. 32 No 4, pp. 91-102. 
Donaldson, T. and Preston, L.E. (1995), "The Stakeholder Theory of the Corporation: Concepts, Evidence, and Implications", Academy of Management Review, Vol. 20 No 1, pp. 65-91.

Ellen, P.S., Mohr, L.A. and Webb, D.J. (2000), "Charitable Programs and the Retailer: Do they Mix?", Journal of Retailing, Vol. 76 No 3, pp. 393-40.

Erdem, T. and Swait, J. (1998), "Brand Equity as a Signaling Phenomenon", Journal of Consumer Psychology, Vol. 7 No 2, pp. 131-157.

Fleck, N.D. and Quester P. (2007), "Birds of a Feather Flock Together... Definition, Role and Measure of Congruence: An Application to Sponsorship", Psychology and Marketing, Vol. 24 No 11, pp. 975-1000.

Folkes, V.S. and Kamins, M.A. (1999), "Effects of Information about Firms' Ethical and Unethical Actions on Consumers' Attitudes", Journal of Consumer Psychology, Vol. 8 No 3, pp. 243-259.

Gray, E.R. and Balmer, J.M.T. (1998), "Managing Image and Corporate Reputation”, Long Range Planning, Vol. 31 No 5, pp. 685-692.

Grbac, B. and Loncaric, D. (2009), "Ethics, Social Responsibility and Business Performance in a Transition Economy", EuroMed Journal of Business, Vol. 4 No 2, pp. 143-158.

Hamlin, R.P. and Wilson, T. (2004), "The Impact of Cause Branding on Consumer Reactions to Products: Does Product/Cause 'Fit' Really Matter?', Journal of Marketing Management, Vol. 20 No 7-8, pp. 663-681.

Hoeffler, S. and Keller, K.L. (2002), "Building Brand Equity through Corporate Societal Marketing”, Journal of Public Policy and Marketing, Vol. 21 No 1, pp. 78-89.

Holbrook, M.B. (1996), "Customer Value: A Framework for Analysis and Research", Advances in Consumer Research, Vol. 23 No 1, pp. 138-142.

Jones, P., Comfort, D. and Hillier, D. (2007), "Corporate Social Responsibility: A Case Study of the Top Ten Global Retailers", EuroMed Journal of Business, Vol. 2 No 1, pp. 23-35.

Kangun, N.L., Carlson, L. and Grove, S.J. (1991), "Environmental Advertising Claims: A Preliminary Investigation", Journal of Public Policy and Marketing, Vol. 10 No 2, pp. 47-58.

Keller, K.L. (1993), "Conceptualizing, Measuring, and Managing Customer-Based Brand Equity", Journal of Marketing, Vol. 57 No 1, pp. 1-22.

Keller, K.L. (2003), Strategic Brand Management: Building, Measuring, and Managing Brand Equity, Prentice Hall, Upper Saddle River, NJ.

Klein, J. and Dawar, N. (2004), "Corporate Social Responsibility and Consumers' Attributions and Brand Evaluations in a Product-Harm Crisis", International Journal of Research in Marketing, Vol. 21 No 3, pp. 203-217.

Kotler, P. and Lee, N. (2005), Corporate Social Responsibility. Doing the Most Good for your Company and your Cause, John Wiley and Sons Inc, Hoboken, NJ.

Krishnan, H.S. (1996), "Characteristics of Memory Associations: A Consumer-Based Brand Equity Perspective", International Journal of Research in Marketing, Vol. 13 No 4, pp. 389405.

Matten D. and Moon, J. (2004), “'Implicit' and 'Explicit' CSR: A conceptual Framework for Understanding CSR in Europe", Proceedings of the $X X^{\text {th }}$ Egos Conference, Ljubljana, Slovenia.

Mitchell, A.A. (1982), "Models of Memory: Implications for Measuring Knowledge Structures", Advances in Consumer Research, Vol. 9 No 1, pp. 45-51. 
Mohr, L.A. and Webb, D.J. (2005), "The Effects of Corporate Social Responsibility and Price on Consumer Responses", The Journal of Consumer Affairs, Vol. 39 No 1, pp. 121-147.

Mohr, L.A., Webb, D.J. and Harris, K.E. (2001), "Do Consumers Expect Companies to be Socially Responsible. The Impact of Corporate Social Responsibility on Buying Behavior", The Journal of Consumer Affairs, Vol. 35 No 1, pp. 45-72.

Morsing, M. (2006), "Corporate Social Responsibility as Strategic Auto-Communication: on the Role of External Stakeholders for Member Identification", Business Ethics: A European Review, Vol. 15 No 2, pp. 171-182.

Motion, J., Leitch, S. and Brodie, R.J. (2003), "Equity in Corporate Co-Branding: The Case of Adidas and the All Blacks", European Journal of Marketing, Vol. 37 No 7/8, pp. 1080-1094.

Müller, B. and Chandon, J-L. (2004), "The Impact of a World Wide Web Site Visit on Brand Image in the Motor Vehicle and Mobile Telephone Industries", Journal of Marketing Communications, Vol. 10 No 2, pp. 153-165.

Murray, K.B. and Vogel, C.M. (1997), "Using a Hierarchy-of-Effects Approach to Gauge the Effectiveness of Corporate Social Responsibility to Generate Goodwill toward the Firm: Financial versus Nonfinancial Impacts", Journal of Business Research, Vol. 38 No 2, pp. 141159.

Obermiller, C. (1995), "The Baby is Sick / The Baby is Well: A Test of Environmental Communication Appeal", Journal of Advertising, Vol. 24 No 2, pp. 55-70.

Park, C.W., Milberg, S. and Lawson, R. (1991), "Evaluation of Brand Extensions: The Role of Product Feature Similarity and Brand Concept Consistency", Journal of Consumer Research, Vol. 18 No 2, pp. 185-193.

Peattie, K., Peattie, S. and Ponting, C. (2009), "Climate Change: A Social and Commercial Marketing Communications Challenge", EuroMed Journal of Business, Vol.4 No 3, pp. 270286.

Pirsch, J., Gupta, S. and Grau, S.L. (2007), "A Framework for Understanding Corporate Social Responsibility Programs as a Continuum: an Exploratory Study", Journal of Business Ethics, Vol. 70 No 2, pp. 125-140.

Roberts, J.A. (1995), "Profiling Levels of Socially Responsible Consumer Behavior: A Cluster Analytic Approach and its Implications for Marketing", Journal of Marketing Theory and Practice, Vol. 3 No 4, pp. 97-117.

Schlegelmilch, B.B. and Pollach, I. (2005), "The Perils and Opportunities of Communicating Corporate Ethics", Journal of Marketing Management, Vol. 21 No 3/4, pp. 267-290.

Schuhwerk, M. and Lefkoff-Hagius, R. (1995), "Green or Non Green? Does Type of Appeal Matter when Advertising a Green Product?", Journal of Advertising, Vol. 24 No 2, pp. 45-54.

Sen, S. and Bhattacharya, C.B. (2001), "Does Doing Good Always Lead to Doing Better? Consumer Reactions to Corporate Social Responsibility", Journal of Marketing Research, Vol. 38 No 2, pp. 225-243.

Sjovall, A.M. and Talk, A.C. (2004), "From Actions to Impressions: Cognitive Attribution Theory and the Formation of Corporate Reputation", Corporate Reputation Review, Vol. 7 No 3, pp. 269-281.

Swaen, V. and Vanhamme, J. (2004), "See how 'Good' we are: The Dangers of Using Corporate Social Activities in Communication Campaigns", Advances in Consumer Research, Vol. 31 No 1, pp. 302-303.

Swaen, V. and Vanhamme, J. (2005), "The Use of Corporate Social Responsibility Arguments in Communication Campaigns: Does Source Credibility Matter?", Advances in Consumer Research, Vol. 32 No 1, pp. 590-591. 
Van de Ven, B. (2008), "An Ethical Framework for the Marketing of Corporate Social Responsibility", Journal of Business Ethics, Vol. 82 No 2, pp. 339-352.

Vanhamme, J. and Grobben, B. (2009), "Too Good to be True! The Effectiveness of CSR History in Countering Negative Publicity”, Journal of Business Ethics, Vol. 85 No 2, pp. 273283.

Van Riel, C.B.M. Van, Stroeker, N.E. and Maathuis, O.J.M. (1998), "Measuring Corporate Image", Corporate Reputation Review, Vol. 1 No 4, pp. 313-326.

Varadarajan, P.R. and Menon, A. (1988), "Cause-Related Marketing: a Co-Alignment of Marketing Strategy and Corporate Philanthropy”, Journal of Marketing, Vol. 52 No 3, pp. 5874.

Yoo, B. and Donthu, N. (2001), "Developing and Validating a Multidimensional ConsumerBased Brand Equity Scale”, Journal of Business Research, Vol. 52 No 1, pp. 1-14. 
Figure 1: Conceptual framework

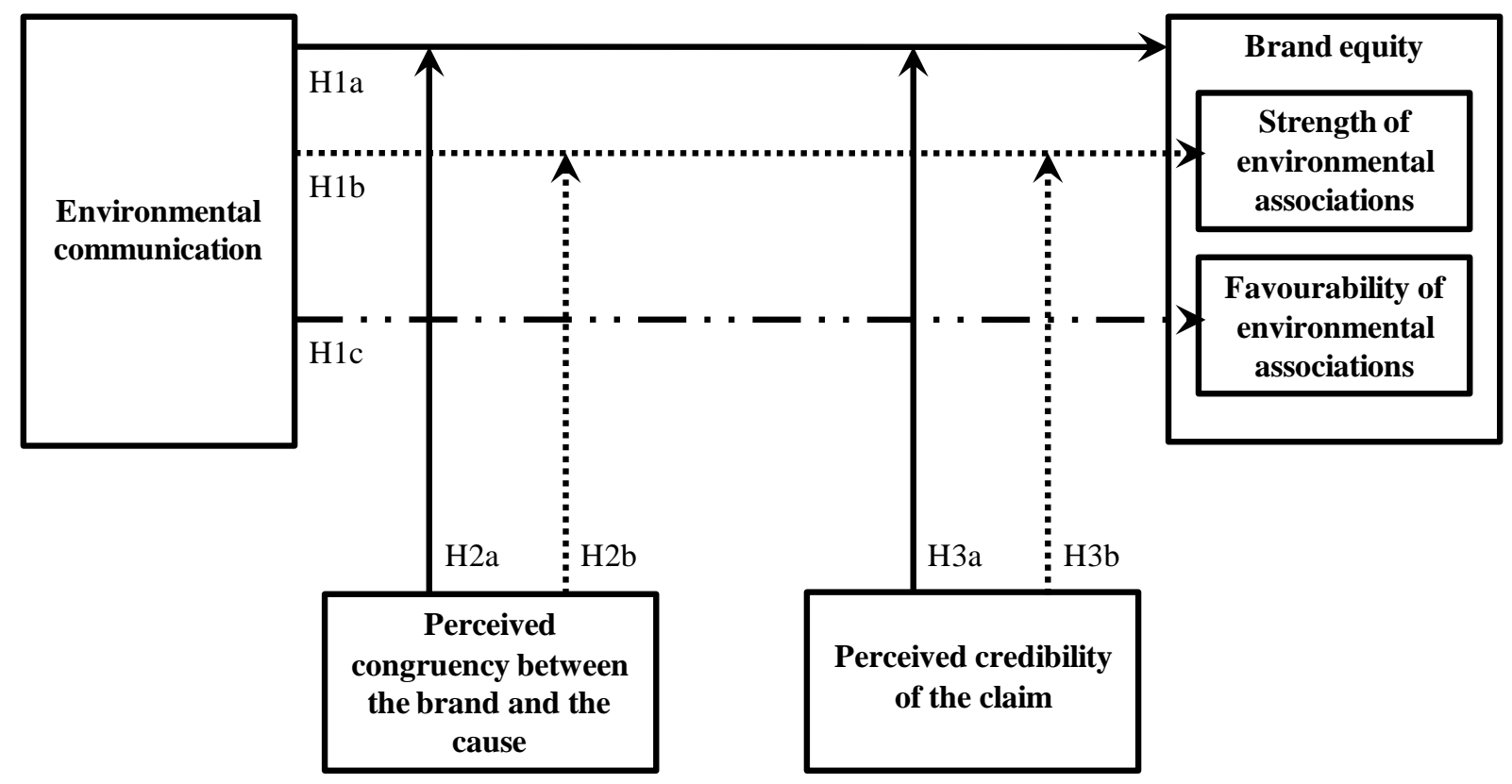


Appendix 1: D'ECO Web site homepage

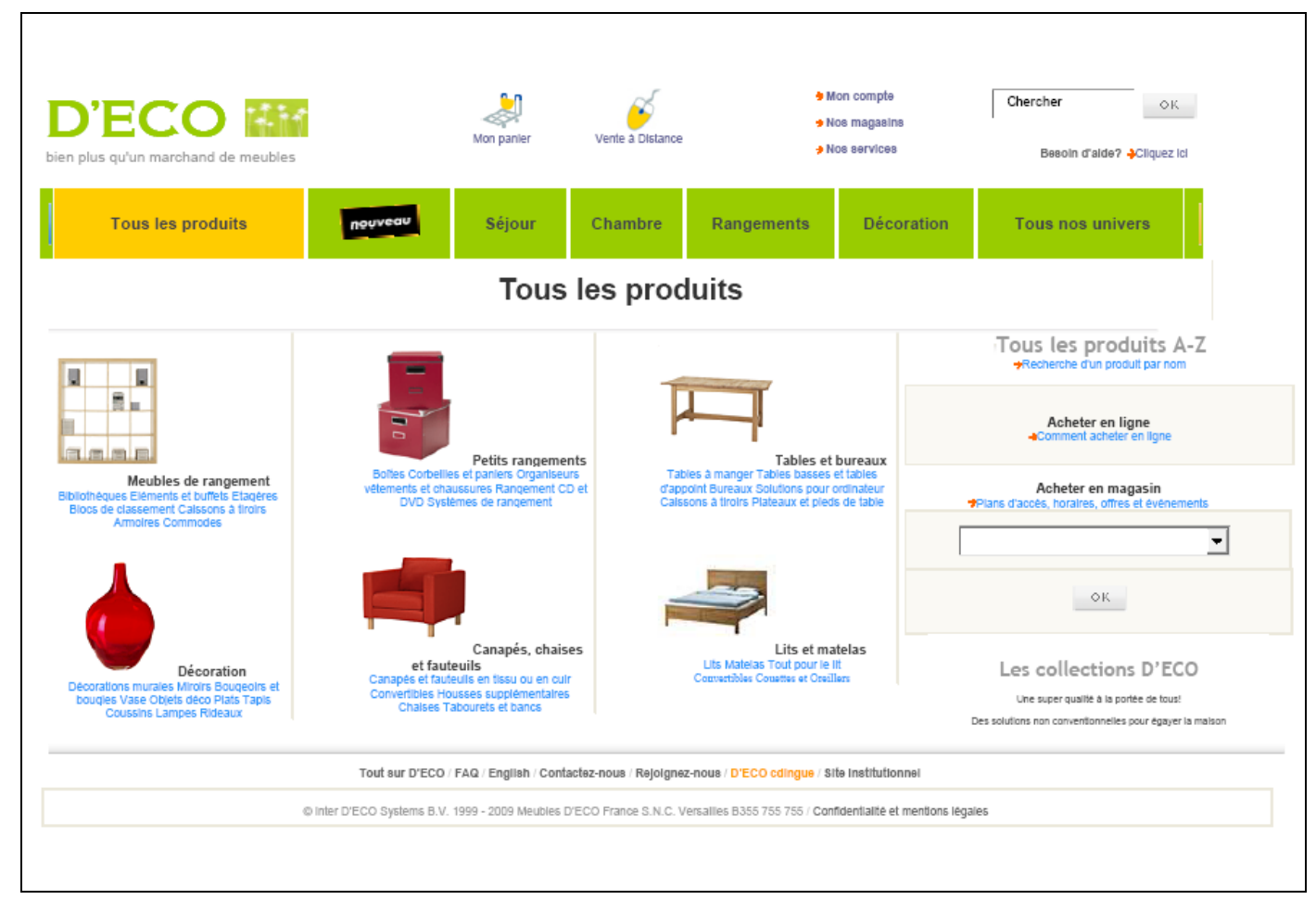




\section{Appendix 2: Brand presentation Web page showing environmental claim}

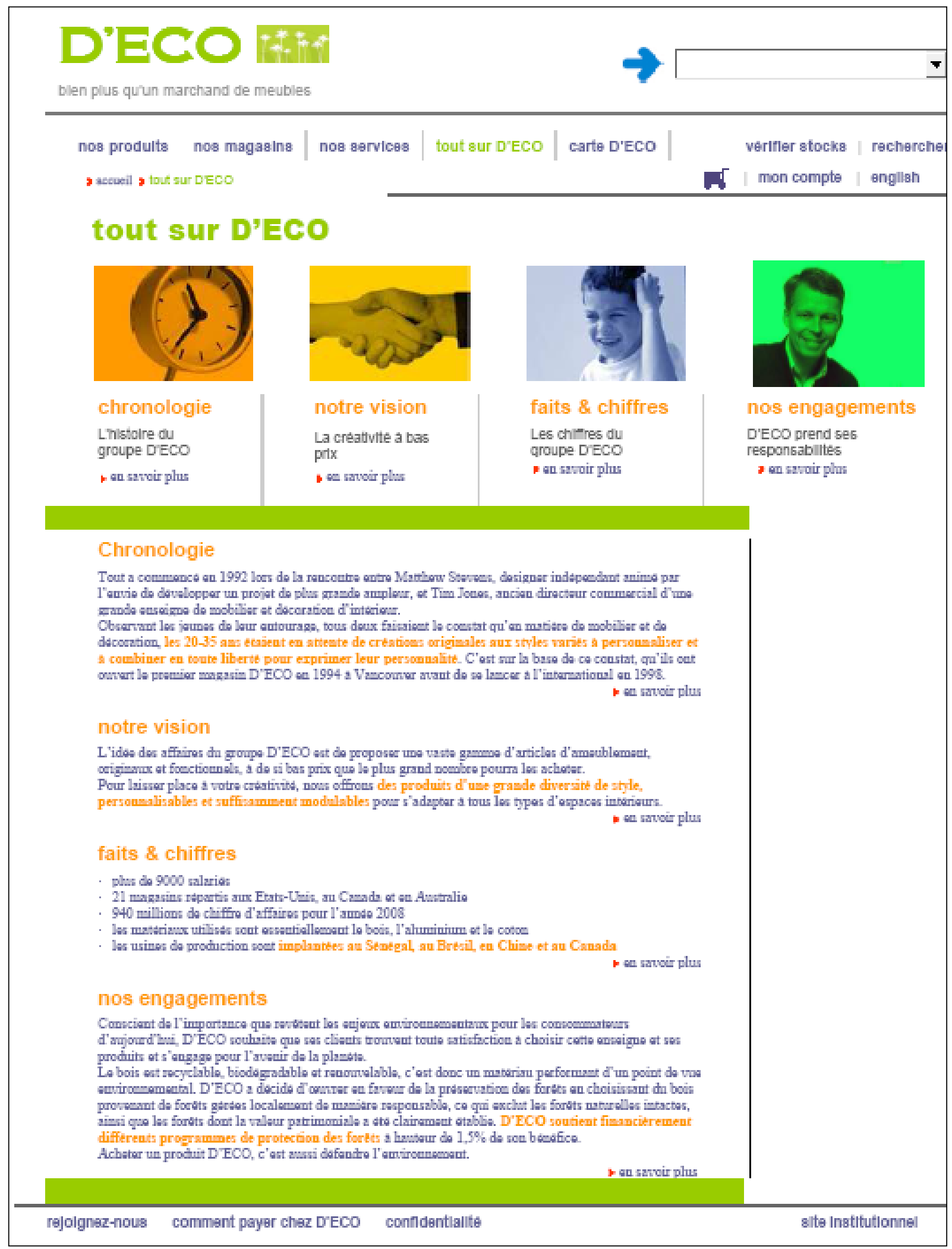

